\title{
Effect of Calcination Time on Bovine-Derived Hydroxyapatite as Bone Implant Material: An In Vitro Study
}

\author{
Jojor Lamsihar Manalu ${ }^{1}$, Francisca Tjhay ${ }^{2}$, Theodora Kristoforus ${ }^{3}$ \\ ${ }^{1}$ Departement of Physiology \\ School of Medicine and Health Sciences Atma Jaya Catholic University of Indonesia \\ Jakarta 14440, Indonesia \\ Email: jojor.lamsihar [AT] atmajaya.ac.id \\ ${ }^{2}$ Departement of Medical Biology \\ School of Medicine and Health Sciences Atma Jaya Catholic University of Indonesia \\ Jakarta 14440, Indonesia \\ Email: francisca.tjhay [AT] atmajaya.ac.id \\ ${ }^{3}$ Departement of Medical Biology \\ School of Medicine and Health Sciences Atma Jaya Catholic University of Indonesia \\ Jakarta 14440, Indonesia \\ Email: theodora2013060036 [AT] student.atmajaya.ac.id \\ *Corresponding author: Jojor Lamsihar Manalu
}

\begin{abstract}
Bone fracture incidence has been increasing, according to recent studies. For a fracture to heal, orthopedic implants are usually employed. One of the bioceramics used is hydroxyapatite (HAp), which has a similar chemical structure with bone mineral and is biocompatible, bioactive as well as non-toxic to the human body. Current methods of HAp synthesis are mostly still toxic to the human body and expensive. Hydroxyapatite originated from natural resources can provide more favorable materials. The purpose of this study is to characterize HAp extracted from bovine bone calcination at $850^{\circ} \mathrm{C}$ for various holding times as bone implant material. The toxicity of the bovine-derived HAp is also assessed. Prepared bovine bones were subjected to calcination at $850^{\circ} \mathrm{C}$ over various holding times. The characterization was carried out with thermogravimetric analysis (TGA) instrument followed by X-ray diffraction (XRD), Scanning Electron Microscopy (SEM), Energy Dispersive X-ray Spectroscopy (EDX) and Fourier-Transform Infrared Spectroscopy (FT- IR). The toxicity of the bovine HAp was assessed using MTT (3-[4, 5-dimethyl-thiazol-2-yl-]-2, 5diphenyltetrazolium bromide) assay. Each of the parameters was compared between the HAp extracted from bovine and the commercial HAp. Analysis of the phase, purity, and crystallinity showed that the bovine-derived HAp was similar to the standard HAp. Crystal agglomeration was observed at increased calcination time. The optimal holding time of 5 hours was demonstrated through the closest Ca/P ratio (1.679) to the stoichiometric $\mathrm{HAp}(\mathrm{Ca} / \mathrm{P}$ ratio $=1.67)$ in $\mathrm{EDX}$ analysis. The toxicity test using the MTT assay showed that the viabilities of CPAE cells treated with bovine HAp were well above 60\% (non-toxic threshold). In conclusion, hydroxyapatite produced from bovine bone calcination at $850^{\circ} \mathrm{C}$ with 5 hours of holding time has the characteristics which are similar to the commercial HAp. This natural HAp has proven to be nontoxic and also cost-effective.
\end{abstract}

Keywords - Hydroxyapatite, Bovine bones, Thermal decomposition, Toxicity

\section{INTRODUCTION}

A discontinuity in the form of crack or complete breakage with a displaced fragment is termed as a bone fracture.[1] In Indonesia, the incidence of bone fractures increased every year. The rate increased by 20188 cases from 2007 ( 22815 cases) to 2010 (43003 cases) [2]. In general, the management of bone fracture involves bone-implant during the bone healing process [3]. Bone implants are synthesized from several biomaterials, which are commonly referred to as orthopedic implants [4]. Orthopaedic implants are specially designed devices to fulfill body functions. The abiotic material has to survive the corrosive environment in the body [4]. The success of an implant or biomaterial is mostly influenced by several factors, one of which the implant biocompatibility. Several implants have the issue of being corrosive [5] hence are toxic in the body. Therefore there is a need for a composite material that can lower the corrosion level and lessen the toxicity of the implant so that the viability of the surrounding cells could be made higher. One of the implant with the quality as mentioned earlier is hydroxyapatite (HAp)[6].

Hydroxyapatite (HAp) is a bioceramic compound that serves as the main matrix of bone and teeth. HAp can be manufactured synthetically by mixing calcium and phosphate under an alkaline condition. Nowadays, HAp is widely used Asian Online Journals (www.ajouronline.com) 
in the medical field for bone tissue material. HAp has chemical resemblance with inorganic bone component because of its superiority in terms of biocompatibility, excellent osteoconductivity and slow biodegradation rate [7-9]. HAp is mainly used on hard material, especially for coating and as a filler. Given that it is non-toxic, biocompatible, non- inflammatory, not inducing an immune response, and has a mesoporous structure, HAp is broadly used. HAp synthesis has been extensively done to repair and replace bone as well as to coat or fill bone and teeth [9].

HAp synthesis can be carried out using many techniques such as sol-gel synthesis, solid-state reaction, co-precipitation, hydrothermal reaction, microemulsion synthesis and mechanochemical synthesis[10-13]. The abundant synthesis methods pose a challenge to find a method that is economical, environmentally friendly, biologically safe, and relatively not complicated but also has low toxicity [8]. One of the methods is heating method or calcination. Bovine bone calcination has been reported to eliminate bacteria or disease-causing agents, and this research produced hydroxyapatite nanocrystalline [14]. Calcination of bovine bone was also carried out by Hilmi et al. (2011) [15].

Synthetic and natural HAp have structural differences [16]. HAp can also be extracted from bovine bone by calcination at various holding temperatures within a specified duration [17]. Bovine-derived HAp has a structure which approximates if not similar to human bone. Past studies had yielded HAp from bovine bone. Bovine bone has calcium phosphate composition as much as 58,3\%; hence it is used to synthesize hydroxyapatite bioceramic (Andy AP, 2015) [18]. The study above employed various temperatures $\left(100^{\circ} \mathrm{C}-1000^{\circ} \mathrm{C}\right)$, with the optimal temperature of $850^{\circ} \mathrm{C}$ for 5 hours of holding time [17], however, the study did not investigate the efficacy of the holding time, and toxicity test was not performed. Therefore the writers are interested in extracting HAp from bovine bone using thermal decomposition process with the calcination temperature of $850^{\circ} \mathrm{C}$ for various holding times with low toxicity.

\section{MATERIALS AND METHODS}

\subsection{Materials}

The bone samples were obtained from male bovine of East Nusa Tenggara. They were rinsed, boiled, and dried.

\subsection{Methods}

The subsequent steps included calcination at $850^{\circ} \mathrm{C}$ over various holding times: $2,3,5$, and 10 hours, followed by homogenization using milling technique with the ball mill ratio of $5: 1$. The milling duration was 6 hours, with constant speed under room temperature. The resulting powder was pressurized at $120 \mathrm{MPa}$ and calcined at $550^{\circ} \mathrm{C}$. The samples were subsequently characterized using X-ray diffraction (XRD), Scanning Electron Microscopy (SEM), Energy Dispersive X-ray Spectroscopy (EDX) and Fourier-Transform Infrared Spectroscopy (FT-IR). The toxicity test was also performed.

\section{RESULTS}

\subsection{Thermogravimetric Analysis (TGA)}

The initial characterization was carried out using a thermogravimetric analysis (TGA) instrument, which has the characterization span from $0^{\circ} \mathrm{C}$ to $1000^{\circ} \mathrm{C}$. The TGA result is demonstrated in Figure 1. Based on the TGA, the bovine HAp had relatively stable weight at temperatures above $800^{\circ} \mathrm{C}$, hence the calcination temperature $850^{\circ} \mathrm{C}$.

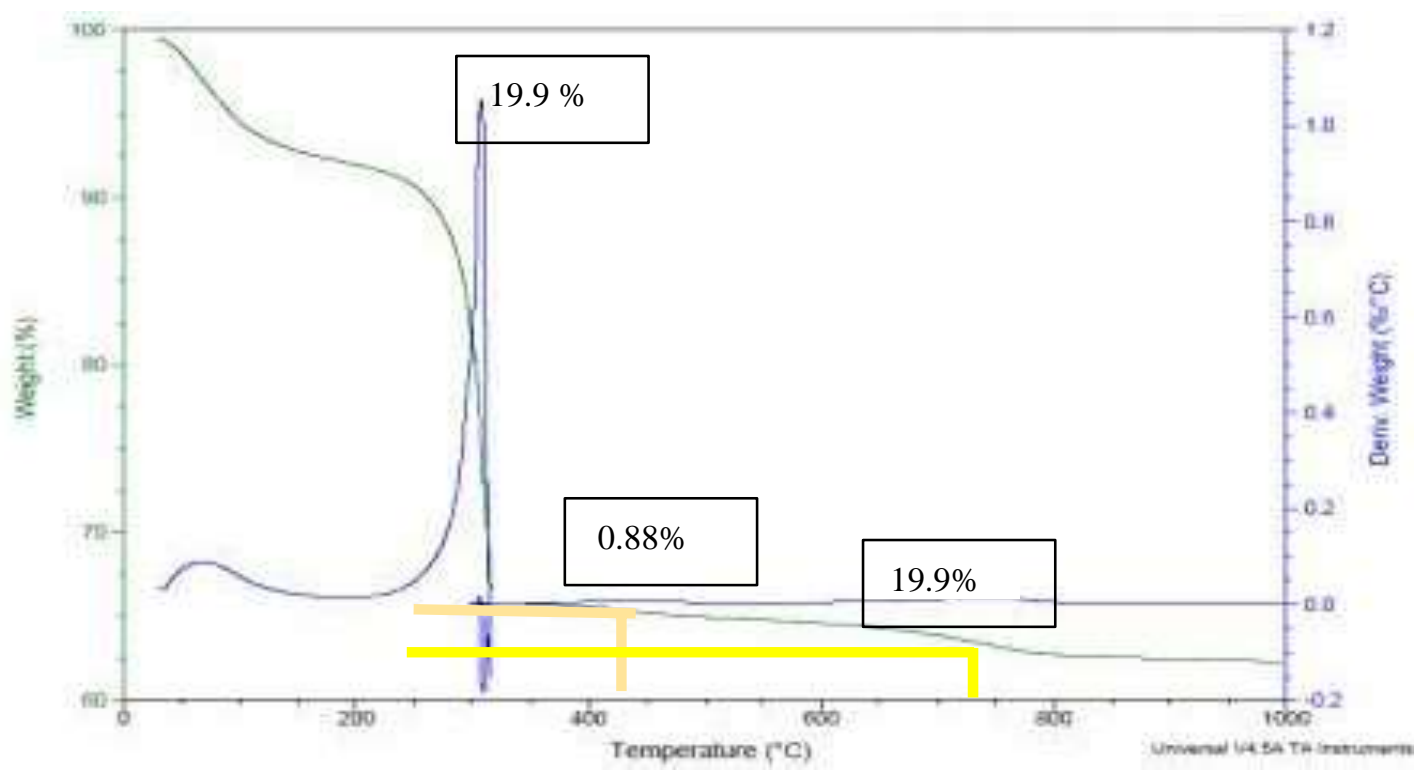

Figure 1: Thermogravimetric Analysis (TGA) of Bovine Bone 


\subsection{X-ray Diffraction (XRD)}

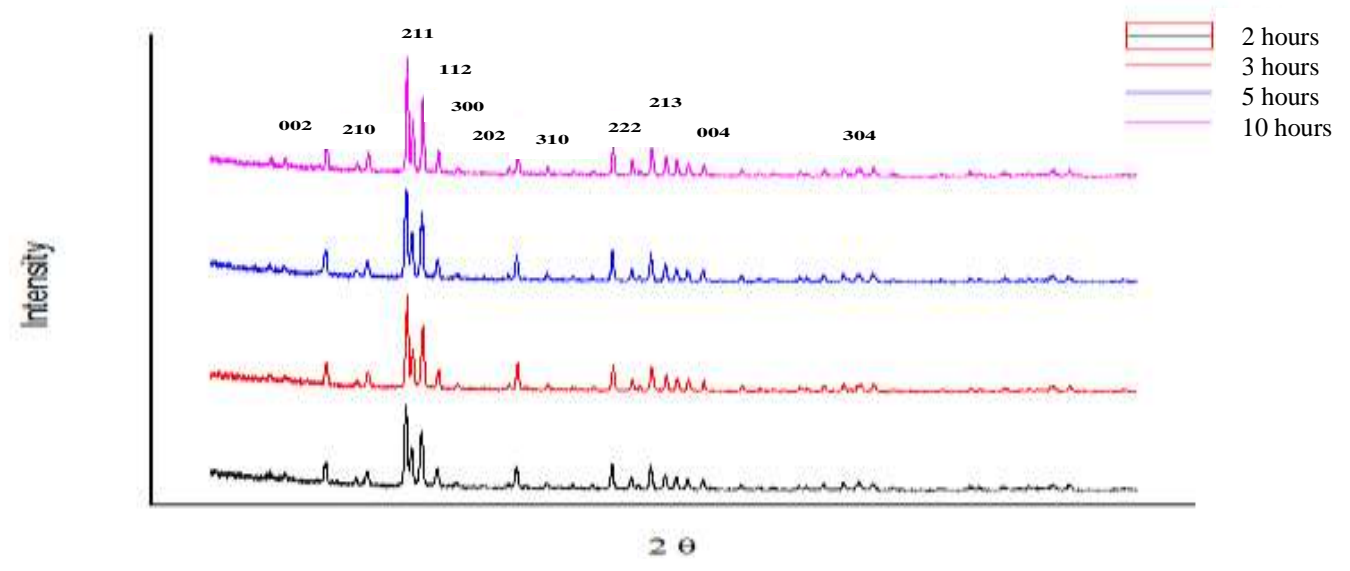

Figure 2: X-ray Diffraction Pattern of Bovine HAp Calcined at $850^{\circ} \mathrm{C}$ with Various Holding Times

Characterization using XRD is needed to identify phases that comprise the sample. The XRD analysis had shown peak patterns that serve as the fingerprint of a compound or phase (Figure 2). Parts of the compound are already known from the EDX analysis. The XRD patterns of the bovine HAp calcined at 2, 3, 5, and 10 hours did not show peak patterns other than that of hydroxyapatite. The patterns were also similar to that of standard hydroxyapatite (JCPDS Joint Committee of Powder Diffraction Standard).

Table 1: Crystal Size, Density, Cell Unit and Crystal System of HAp Derived from Bovine Bone Calcination at $850^{\circ} \mathrm{C}$ with

\begin{tabular}{|c|c|c|c|c|c|}
\hline \multicolumn{6}{|c|}{ Various Holding Times } \\
\hline No & $\begin{array}{c}\text { Calcination } \\
\text { Time }\end{array}$ & Crystal Size & Density & Cell Unit & $\begin{array}{l}\text { Crystal } \\
\text { System }\end{array}$ \\
\hline 1 & 2 hours & $457.3 \mathrm{~A}^{\circ}$ & $2.7268 \mathrm{~g} / \mathrm{cm}^{3}$ & $\begin{array}{c}\mathrm{a}=\mathrm{b}=9.40928 \\
\mathrm{c}=6.8696\end{array}$ & $\begin{array}{c}\text { Hexagonal } \\
\alpha=\beta=90^{\circ} \text { : } \\
\gamma=120^{\circ}\end{array}$ \\
\hline 2 & 3 hours & $502.3 \mathrm{~A}^{\circ}$ & $2.7182 \mathrm{~g} / \mathrm{cm}^{3}$ & $\begin{array}{c}a=b=9.39756 \\
c=6.86525\end{array}$ & $\begin{array}{c}\text { Hexagonal } \\
\alpha=\beta=90^{\circ} \text { : } \\
\gamma=120^{\circ}\end{array}$ \\
\hline 3 & 5 hours & $513.5 \mathrm{~A}^{\circ}$ & $2.7509 \mathrm{~g} / \mathrm{cm}^{3}$ & $\begin{array}{c}a=b=9.39756 \\
c=6.86525\end{array}$ & $\begin{array}{c}\text { Hexagonal } \\
\alpha=\beta=90^{\circ}: \\
\gamma=120^{\circ}\end{array}$ \\
\hline 4 & 10 hours & $738.3 \mathrm{~A}^{\circ}$ & $2.7486 \mathrm{~g} / \mathrm{cm}^{3}$ & $\begin{array}{c}a=b=9.40471 \\
c=6.87054\end{array}$ & $\begin{array}{c}\text { Hexagonal } \\
\alpha=\beta=90^{\circ}: \\
\gamma=120^{\circ}\end{array}$ \\
\hline
\end{tabular}

HAp crystal size was shown to increase along with calcination holding time (Table 1, Figure 3). HAp which was calcined for 2 hours had the crystal size of $457.3 \mathrm{~A}^{0}$ or about $45.73 \mathrm{~nm}$, while HAp yielded from 3 hours of calcination holding time was $502.3 \mathrm{~A}^{0}(50.23 \mathrm{~nm})$ in size. Crystal size of HAp produced from bovine bone calcinated for 5 hours and 10 hours were $513.5 \mathrm{~A}^{0}(51.35 \mathrm{~nm})$ and $738.3 \mathrm{~A}^{0}(73.83 \mathrm{~nm})$, respectively. Cell unit and crystal system of the bovine-derived HAp were similar to that of the standard HAp.

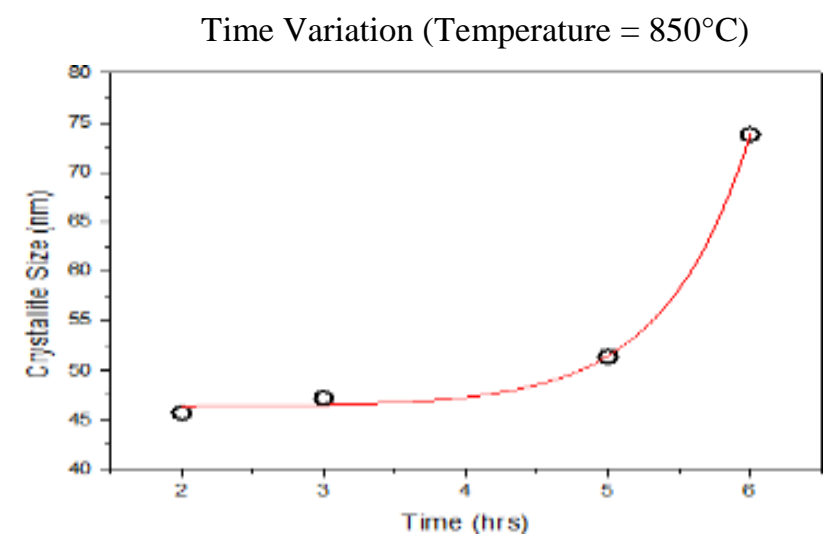

Figure 3: Crystal Size at Increasing Calcination Time 


\subsection{Scanning Electron Microscopy (SEM)}

Figure 4 below shows the scanning electron microscopy of the surface morphology and size of crystal derived from bovine HAp.

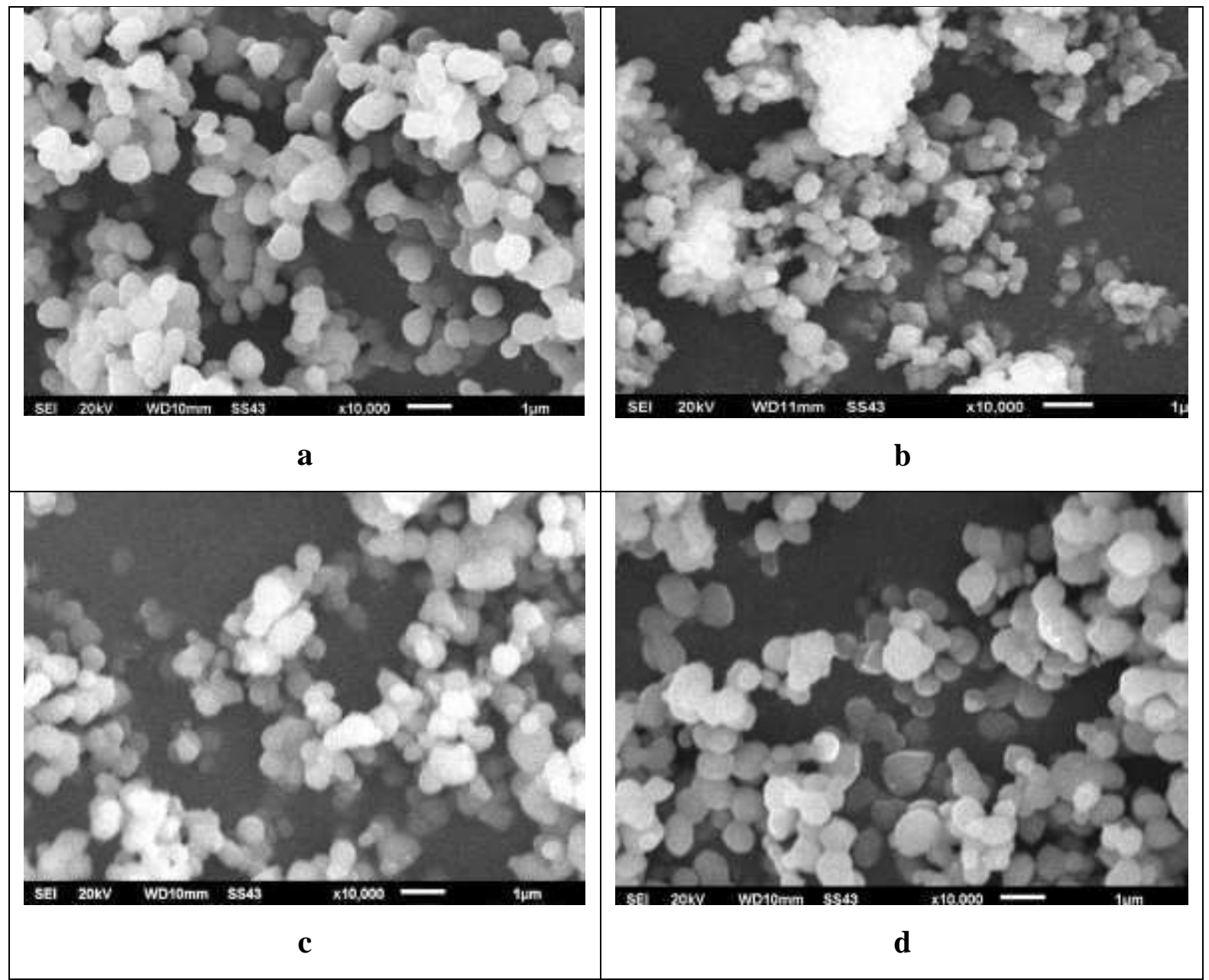

Figure 4: Scanning electron microscopy of the Bovine HAp at $850^{\circ} \mathrm{C}$ for 2 hours (a), 3 hours (b), 5 hours (c) and 10 hours (d)

\subsection{Energy Dispersive X-ray Spectroscopy $(E D X)$}

EDX characterization of bovine bone calcined at $850^{\circ} \mathrm{C}$ with holding time variation ( 2 hours, 3 hours, 5 hours, and 10 hours) is depicted in table 2.

Table 2: $\mathrm{Ca} / \mathrm{P}$ ratio of Bovine HAp Calcined at Different Holding Times

\begin{tabular}{l|c|c|c|c}
\hline No & $\begin{array}{c}\text { Calcination } \\
\text { Time }\end{array}$ & Ca & $\mathbf{P}$ & $\mathbf{C a} / \mathbf{P}$ \\
\hline $\mathbf{1}$ & 2 hours & 20.54 & 15.54 & 1.321 \\
$\mathbf{2}$ & 3 hours & 33.09 & 9.19 & 3.600 \\
$\mathbf{3}$ & 5 hours & 33.45 & 19.92 & 1.679 \\
$\mathbf{4}$ & 10 hours & 31.33 & 19.77 & 1.584 \\
\hline
\end{tabular}

\subsection{Fourier-Transform Infrared Spectroscopy (FT-IR)}

Characterization using FT-IR was carried out to examine the functional group in the sample. This test gives authentic information about the vibration source of the phosphate, carbonate, and amide group to confirm the HAp purity that is not contaminated by other organic elements. FT-IR is an infrared spectroscopy technique that can identify complex groups in a calcium phosphate compound but is unable to determine the composing elements. 


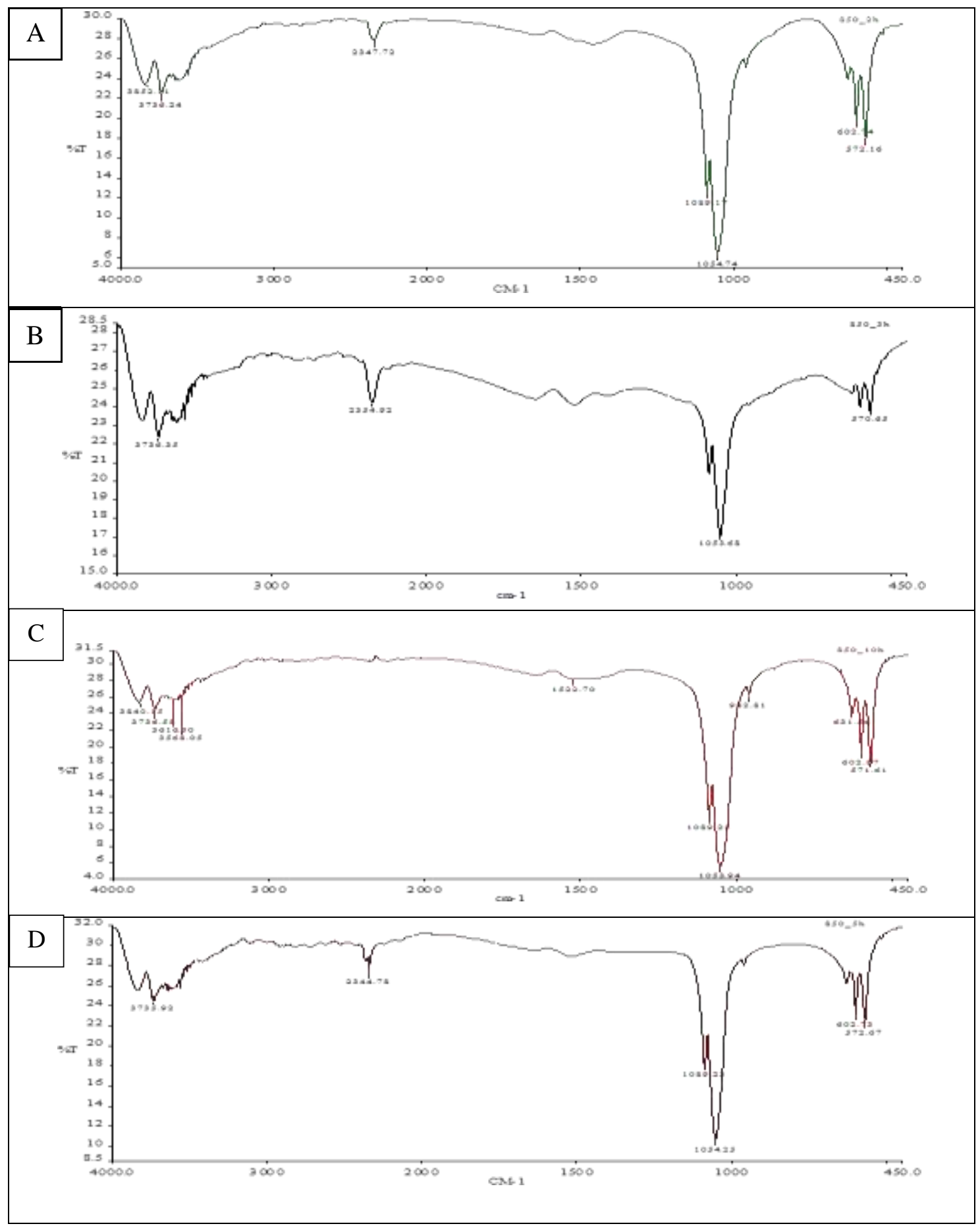

Figure 5: FT-IR Results of Bovine Bone HAp Produced from Calcination at $850^{\circ} \mathrm{C}$ for 2 hours (a), 3 hours (b), 5 hours (c) and 10 hours $(d)$ 


\subsection{Toxicity Test}

The toxicity test results of the sterilized Mg-HAp composites are shown in Table 3.

Table 3: Results of Viability Test

\begin{tabular}{l|c|c|c|c|c}
\hline \multirow{1}{*}{ Sample } & \multicolumn{5}{|c}{ Viability (\%) } \\
\cline { 2 - 6 } & Control & $\mathbf{0 . 0 0 1 / 1 0 0 0}$ & $\mathbf{0 . 1} / \mathbf{1 0 0}$ & $\mathbf{1 0 / 1 0 0}$ & $\mathbf{1 0 0 / 1 0 0}$ \\
\hline $\begin{array}{l}\text { Bovine HAp } 850^{\circ} \mathrm{C} \\
\text { (10 hours) }\end{array}$ & 100 & 106.16 & 78.17 & 103.17 & 79.03 \\
Bovine HAp $850^{\circ} \mathrm{C}$ (5 & 100 & 94.72 & 77.99 & 89.61 & 89.79 \\
hours) & 100 & 167 & 151 & 111 & 85 \\
Sigma-Aldrich HAp & & &
\end{tabular}

\section{DISCUSSION}

\subsection{X-ray Diffraction (XRD)}

Bovine HAp crystal phase obtained at different calcination times was analyzed with X-Ray Diffraction (XRD). The resulting peak patterns depict the fingerprint of the compound or phase. Identification of these peak patterns is part of qualitative XRD analysis. The phase or compound can be determined but not the percentage of each compound.

Figure 2 shows the XRD pattern of bovine bone calcined at $850^{\circ} \mathrm{C}$ with holding time variations of $2,3,5$, and 10 hours as diffraction line position $(2 \theta)$ and relative intensity (I). The HAp produced from bovine bone calcination at $850^{\circ} \mathrm{C}$ with various holding times showed narrowing peaks with higher intensity and sharp resolution, indicating that some organic material is lost, and the peaks approximate XRD peaks of commercial (ex Aldrich) HAp.

These XRD results demonstrate that the HAp stability in the bone matrix is inseparable at calcination temperature of $850^{\circ} \mathrm{C}$ with holding times $2-10$ hours. The result also proves true with the HAp chemical structure, which is not influenced and no peak patterns other than that of HAp patterns. The HAp from bovine bone calcined at $850^{\circ} \mathrm{C}$ with various holding times resembles the standard HAp (JCPDS Joint Crystal Powder Diffraction Standard-09-0432/1996). From Table 1 and Figure 3, it is evident that the crystal size increases with longer calcination time.

Scanning Electron Microscopy (SEM)Figures 4a, b, c, and d demonstrate the SEM results of HAp from bovine bone calcined at $850^{\circ} \mathrm{C}$ with holding times of $2,3,5$, and 10 hours. The surface morphology and crystal size were examined using SEM. The bovine HAp is shown to have uniform particle size and shape, pore size and distribution, as well as the presence of interconnections. The pores are formed as the result of the presence of empty space due to stretching and release of porogen particles from HAp particle trapped during heating [8]. On the other hand, the interconnections of the pores result from the release of the porogen particle to the material surface or the other pore. The particle size and shape, pore size, homogeneous distribution, and interconnections observed from the SEM results are similar to that of pure hydroxyapatite (Figure 5).

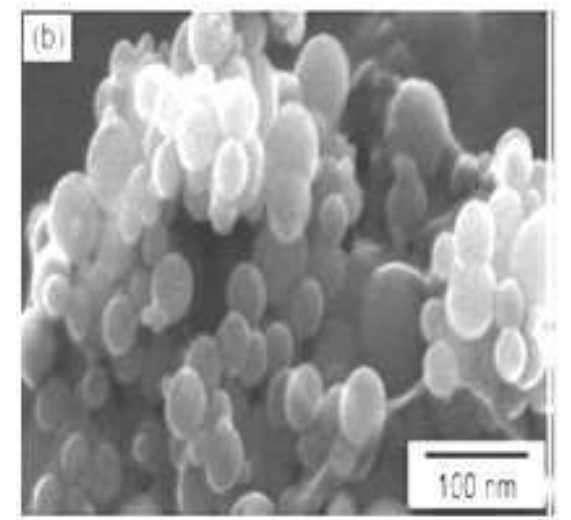

Figure 5: Scanning Electron Microscopy (SEM) Image of Pure HAp

\subsection{Energy Dispersive X-ray Spectroscopy (EDX)}

The characterization of calcined bovine bone is depicted in Table 2. The holding time variations were 2 hours, 3 hours, 5 hours, and 10 hours. For all calcination holding times, the dominant element in calcined bovine bone sample is Calcium (Ca) followed by Phosphor (P) with 20-34\% Ca atom and 9-20\% $\mathrm{P}$ atom.

$\mathrm{Ca}$ and $\mathrm{P}$ are the two main elements from which the ratio can be calculated. The HAp powder of bovine bone calcined at $850{ }^{\circ} \mathrm{C}$ for 2 hours shows the $\mathrm{Ca} / \mathrm{P}$ ratio of 1.321 . For calcination time of 3 hours, the $\mathrm{Ca} / \mathrm{P}$ ratio is 3.600 . Furthermore, the $\mathrm{Ca} / \mathrm{P}$ ratio is 1.679 for 5 hours of calcination holding time. The calcination time of 10 hours yield $\mathrm{Ca} / \mathrm{P}$ ratio of 1.584 . It 
can be seen that there is no association between calcination holding time and $\mathrm{Ca} / \mathrm{P}$ ratio. The calcination holding time of 5 hours produced HAp with $\mathrm{Ca} / \mathrm{P}$ ratio (1.679) that had the closest approximation to the $\mathrm{Ca} / \mathrm{P}$ ratio of stoichiometric hydroxyapatite (1.67).

\subsection{FT-IR Analysis}

Characterization using FT-IR was carried out to identify the functional group in the sample. This test shows authentic information regarding the vibration source of phosphate, carbonate, and amide group to confirm pure HAp synthesis without other organic elements. FT-IR is an infrared spectroscopy technique that can identify a complex group in a calcium phosphate compound but is unable to identify the consisting elements. In infrared spectroscopy, the infrared spectrum is located at the wavelength of 0.78 to $1000 \mu \mathrm{m}$ or wavenumber of 12800 to $1 \mathrm{~cm}^{-1}$. From the application and instrumentation point of view, the infrared spectrum is divided into three kinds of radiation, namely near-infrared (wavenumber $12800-400 \mathrm{~cm}^{-1}$ ), midinfrared (wavenumber $4000-200 \mathrm{~cm}^{-1}$ ) and far- infrared (wavenumber $200-10 \mathrm{~cm}^{-1}$ ). FT-IR is included in mid-infrared radiation (wavenumber $4000-200 \mathrm{~cm}^{-1}$ ). Transmittance and wavenumber plot will produce an infrared spectrum. Each type of different bond has different vibration frequencies in a slightly different environment. Hence two molecules with differing structures do not share the same infrared absorbance or spectrum [19].

\subsection{Toxicity Test}

Toxicity test results of sterilized bovine HAp calcined at $850{ }^{\circ} \mathrm{C}$ with holding time variations are shown through the CPAE cell viability (Table 3 ). The test reveals good viability percentage at all concentrations of HAp extracted from bovine bone calcined at $850^{\circ} \mathrm{C}$ with holding time of 5 hours and 10 hours. The good viability shows that bovine HAp extract calcined at $850^{\circ} \mathrm{C}$ with 5 and 10 hours holding time does not inhibit CPAE cell growth. Toxicity test using the MTT (3-[4, 5- dimethylthiazol-2-yl-]-2, 5-diphenyltetrazolium bromide) assay showed that the viabilities of CPAE cells treated with bovine HAp at $0.001 / 100,0.1 / 100,10 / 100$ and $100 / 100$ concentrations were above $60 \%$, which is the minimum cell viability for body implant material [2].

Through the toxicity test using MTT, it can be known that the yielded composite matrix is safe and does not induce toxicity. In this test, the Elisa reader instrument (Thermo Scientific) with a wavelength of $620 \mathrm{~nm}$ was employed. The toxicity criteria mention that material is regarded as not toxic if the reading of the measurement results is more than $60 \%$; in other words, more than $60 \%$ of viable cells are present.

From Table 3, it can be inferred that the extract of $\mathrm{Mg}$-HAp composite at calcination time of $850^{\circ} \mathrm{C}$ does not inhibit CPAE cell growth for the calcination time of 5 hours as well as 10 hours; however, the cell viability is higher at 5 hours holding time.

\section{CONCLUSION}

Hydroxyapatite can be yielded from bovine bone calcination at $850{ }^{\circ} \mathrm{C}$ over 5 hours of holding time. This hydroxyapatite has the characteristics which correspond to that of commercial hydroxyapatite. The degree of bovine bone crystallinity increases with the rise of calcination temperature. Calcination temperature increase influences the $\mathrm{Ca} / \mathrm{P}$ ratio of bovine bone HAp, albeit not linearly.

The toxicity test shows the hydroxyapatite produced from bovine bone calcined at $850^{\circ} \mathrm{C}$ with 5 hours of holding time demonstrates good CPAE cell growth of $77.99-94.72 \%$. Hence the sample can be used as an implant material.

The economical nature, safety, relatively easy manufacturing process as well as its biocompatibility make bovine-derived HAp an excellent option for bone implant material. The bovine HAp has the advantage of inheriting the raw material characteristics such as chemical composition and structure.

\section{ACKNOWLEDGMENT}

This research was supported by Atma Jaya Catholic University of Indonesia Research Grant 2018/2019.

\section{REFERENCES}

[1] Graham, A., Solomon, L., Buku Ajar Ortopedi dan Fraktur Sistem Apley Edisi 7, Widya Medika, Jakarta, 1997.

[2] Triono, P., Murinto, “Aplikasi Pengolahan Citra Untuk Mendeteksi Fraktur Tulang Dengan Metode Deteksi Tepi Canny”, Jurnal Informatika, vol. 9, no. 4, 2015.

[3] Brydone, A.S., Meek, D., Maclaine, S., "Bone grafting, orthopedic biomaterials, and the clinical need for bone engineering”, Proceedings of the Institution of Mechanical Engineers, Part H: Journal of Engineering in Medicine, vol. 224, no.12, pp.1329-1343, 2010.

[4] Schmalz, G., Arenholt-Bindslev, D., Biocompatibility of dental materials, Springer, Berlin, 2009.

[5] Manivasagam, G., Dhinasekaran, D., Rajamanickam, A., "Biomedical Implants: Corrosion and its Prevention - A Review”, Recent Patents on Corrosion Science, vol. 2, no. 1, pp.40-54, 2010.

[6] Aksakal, B., Yildirim, Ö. S., Gul, H., "Metallurgical failure analysis of various implant materials used in orthopedic 
applications", Journal of Failure Analysis and Prevention, vol. 4, no. 3, pp.17-23, 2004.

[7] Fathi, M.H., Hanifi A., Mortazavi V., "Preparation And Bioactivity Evaluation Of Bone-Like Hydroxyapatite Nanopowder", Journal Of Materials Processing Technology, vol. 202, pp. 536-542, 2008.

[8] Barakat, N.A.M., Khil, M.S., Omran, A.M., Sheikh, F.A., Kim, H.Y., "Extraction of pure natural hydroxyapatite from the bovine bones biowaste by three different methods", Journal of Materials Processing Technology, vol. 209, no. 7, pp. 3408-3415, 2009.

[9] Zhou, H., Lee, J., "Nanoscale hydroxyapatite particles for bone tissue engineering”, Acta Biomaterialia, vol. 7, no. 7, pp. 2769-2781, 2011.

[10] Ferraz, M.P., Monteiro, F.J., Manuel, C.M., "Hydroxyapatite nanoparticles : A review of preparation methodologies", Journal of Applied Biomaterials \& Biomechanics, vol. 2, pp. 74-80, 2004.

[11] Ooi, C. Y., Hamdi, M., Ramesh, S., "Properties of hydroxyapatite produced by annealing of bovine bone", Ceram. Int., vol. 33, pp. 1171-1177, 2007.

[12] Dachun, L., Wei, C., "Preparation and characterization of natural hydroxyapatite from animal hard tissues", Key Eng. Mat., vol. 342, pp. 343, 2007.

[13] Ivankovic, H., Gallego Ferrer, G., Tkalcec, E., Orlic, S., Ivankovic, M., "Preparation of highly porous hydroxyapatite from cuttlefish bone”, J. Mater. Sci.-Mater. Med., vol. 20, pp. 1039-1046, 2009.

[14] Ruksudjarit, A., Pengpat, K., Rujijanagul, G., Tunkasiri, T., "Synthesis and characterization of nanocrystalline hydroxyapatite from natural bovinebone", Current Applied Physics, vol. 8, pp. 270-272, 2008.

[15] Hilmi, I., Rinastiti, M., Herliansyah, M.K., "Synthesis of Hydroxyapatite from local Bovine Bones for Biomedical Application", In International Conference on Instrumentation, Communication, Information Technology and Biomedical Engineering, Bandung, Indonesia, 2011.

[16] Tan, L., Yu, X., Wan, P., Yang, K., "Biodegradable Materials for Bone Repairs: A Review”, J Mater Sci Technol., vol. 29, no. 6, pp. 503-313, 2013.

[17] Manalu, J.L., Soegijono, B., Indriani, D.J., “Characterization of Hydroxyapatite Derived from Bovine Bone”, Asian J Appl Sci., vol. 35, no. 24, pp. 6299-6310, 2015.

[18] Andy, A.P., "Ekstraksi dan karakterisasi hidroksiapatit dari limbah kerajinan tulang sapi”, Bachelor (thesis), Bali: Univesitas Udayana, 2015. Available from: http://erepo.unud.ac.id/9316/.

[19] Koutsopoulos, S., "Synthesis and characterization of hydroxyapatite crystals: A review study on the analytical methods", J. Biomed. Mater. Res., vol. 62, pp. 600-612, 2002. 